\title{
Seasonal variation and characterization of effluents of fertilizer factory
}

\author{
K Fatima, MK Hossain, MA Islam*
}

Department of Environmental Science, Faculty of Agriculture, Bangladesh Agricultural University, Mymensingh-2202, Bangladesh.

\begin{abstract}
The study was carried out to assess the water quality of the Jamuna river affected by effluents discharged from the nearby Jamuna Fertilizer Company Limited and its temporal change over wet and dry seasons due to change of the physico-chemical parameters. Effluents of the factories and water samples were collected from four different selected stations during the period of June to August 2014 and January to March 2015.The results further revealed that the water samples showed a remarkable variation in physico-chemical parameters during the wet and dry season. In wet season the mean value of temperature, pH, EC, TDS, TSS, DO, BOD, ammonium, nitrite, nitrate and chloride were28.63 $\pm 3.79{ }^{\circ} \mathrm{C}, 8.10 \pm 0.85,664.41 \pm 599.54 \mu \mathrm{scm}^{-1}, 370.91 \pm$ 111.38 ppm, $74.49 \pm 25.90$ ppm, $6.11 \pm 1.28$ ppm, $75.39 \pm 140.86$ ppm 296.74 \pm 303.03 ppm, $12.31 \pm 21.38$ ppm, $15.19 \pm 24.49 \mathrm{ppm}$ and $15.23 \pm 8.72 \mathrm{ppm}$, respectively In the dry season the mean value of temperature, $\mathrm{pH}, \mathrm{EC}$, TDS, TSS, DO, BOD, ammonium, nitrite, nitrate and chloride were31.69 $\pm 3.18^{\circ} \mathrm{C}, 8.44 \pm 0.66$, 786.25 $\pm 551.18 \mu \mathrm{scm}^{1}$, 338.37 94.70 ppm, $72.08 \pm 58.83$ ppm, $5.45 \pm 0.95$ ppm, $86.93 \pm 159.82$ ppm, $347.91 \pm$ $291.60 \mathrm{ppm}, 13.68 \pm 23.1 \mathrm{ppm}, 18.34 \pm 24.92 \mathrm{ppm}$ and $18.3 \pm 9.32 \mathrm{ppm}$, respectively. The comparative study showed that most of the effluent and water quality parameters were higher in dry season than those of the wet season because in dry season less quantity of water remains in the river and in wet season more water remains in river that has great dilution capacity. For existence and conservation of aquatic resources, it is essential to investigate the water quality and surrounding environment of the river.
\end{abstract}

Key words: Effluents, physicochemical properties, water quality

Progressive Agriculturists. All rights reserve

*Corresponding Author: maislam@bau.edu.bd

\section{Introduction}

Water is essential for the survival of any forms of life. The quality of water is of vital concern for mankind since it is directly linked with human welfare. Water accounts for about $70 \%$ of the weight of a human body and about $80 \%$ of the earth's surface is covered by water (Buchholz, 1998). Water is also indispensable for agriculture, manufacturing, transportation and many other human activities. Despite its importance, water is the most poorly managed resource in the world (Fakayode, 2005).With a marked rise in population, a rapid growth of towns and industries, a great in irrigation as well as demand for pure water is gradually increasing. Industries such as urea fertilizer, paper mills, tanneries and oil refineries etc. demand supply of clear water. These are therefore, usually established in the bank of rivers where water is readily available for power and manufacturing purposes. Ironically enough, these industries discharged large volume of their liquid and solid wastes as well as crude sewage into the rivers (Klein, 1962).

In Bangladesh, industrial units are mostly located along the banks of the rivers. House as well as industry consume water and give out wastewater. Industrial wastewater is the effluent delivered out of a particular industry. Its quality and quantity depends upon nature of industry, raw materials used, manufacturing process and housekeeping. Their 
characteristics vary widely from industry to industry. Unfortunately as a consequence, industrial units drain effluents directly into the rivers without any consideration of the environmental degradation. The most problematic industries for the water sector are textiles, tanneries, pulp and paper mills, fertilizer, industrial chemical production and refineries. A complex mixture of hazardous chemicals, both organic and inorganic, is discharged into the water bodies from all these industries usually without treatment. The highest numbers of industrial establishments in the country are located in the North Central (NC) region, which comprises about 49 percent of the total sector (WARPO, 2000a).

Urea fertilizer industries form an important segment of total chemical industry in Bangladesh (Alamet al., 1997). Urea fertilizers are used of a huge amount in Bangladesh in order to grow more food to meet the increasing demand of food. There are seven urea fertilizer factories scattered all over the Bangladesh involving vast area and huge man power. Jamuna Fertilizer Company Ltd. Tarakandi, Jamalpur, is an installation in the country contributing significantly to the production of urea. Fertilizer factory is one of the most important sources of water pollution. Jamuna Fertilizer Company Limited (JFCL) is one of them. The liquid wastes generated from the production process are discharged from the complex to the environment which finally goes to the Jamunariver and to the cultivated land adjacent to the complex. Contamination of land and water can occur either from deposition of material originally introduced into the atmosphere or from waste products discharged directly to the ground, surface or subsurface waters from which they are eventually mobilized by ground water or erosion. Spill over from manufactures of acids used as raw materials; spill over the final fertilizer products; boiler blowdown, cooling water etc. are responsible for discharging a large amount of waste water (treated or untreated) into the river. Sever water pollution effect human life by causing different short term and long term diseases who use these river water for their daily needs. To save the productivity and other resources of our water body, it is very essential to work for the Environmental Impact Assessment
(EIA) and the effect of pollution on growth, development, reproduction and process of life cycle of aquatic organisms. For the above causes there need a study to assess the environmental impact of the effluent discharged by the Jamuna fertilizer Company Ltd. to the adjacent Jamuna river and recommendations for prevention and recycling the pollution of water for the next as well as present generation.

Environmental impact of effluent discharge to the Jamunariver, water pollution, physico-chemical parameters of the discharge effluent and its impact is the vast topic to resolve. It deals with various events about chemical, physical, physico-chemical properties of discharge effluent and river water. To analyze the physico-chemical parameters of the effluents and to find out the change in the physicochemical parameters of the water body of the Jamuna river where the effluents are discharged was an analytical as well as descriptive research whose principal objectives is to realize the degradation of water quality and its environmental impact. Different organization and NGO's developing awareness about the harmful impact which is helpful for the govt. and different regulatory and legislative body for taking initiatives to protect the vulnerable environment (Ahmad, 2012).

The objectives of the study were to determine the physico-chemical characteristics of the effluent discharged from Jamuna Fertilizer Company Limited (JFCL) and to compare the waste water quality of the study area with the existing standards.

\section{Materials and Methods}

Study area: The study area is situated at Tarakandi of Sarishabari in Jamalpur district, at the bank of Jamuna river which is the most economically important for communicating to north region of the country with Dhaka and for maintaining livelihood of the people livinig in the surroundidg area. The geographic location of the study area is latitude $24^{\circ}$ $39^{\prime} \mathrm{N}$ and longitude $89^{\circ} 50^{\prime} \mathrm{E}$.

Data collection: The research was based on both primary and secondary data. Primary data were collected through field observation and on laboratory 
work and secondary data were collated from governmental organization, personal records, journals and papers (published and unpublished) articles, and from electronic and web based information.

Sample collection: Twenty four samples of effluents and discharge water were collected from four different stations of the study area by monthly in both wet (June-August) and dry (January-March) seasons. The sampling points which are namely: station-1 (Industrial effluent); station-2 (water of effluent disposal point); station-3 (100 m downstream of river water from disposal point) and station-4 (200 m downstream of river water from disposal point). Samples were collected in $1000 \mathrm{ml}$ plastic bottles from every points of the study area for the analysis of temperature, turbidity, $\mathrm{pH}, \mathrm{EC}$, TDS, TSS, DO, BOD, nitrite, nitrate, ammonium. Prior to sample collection, bottle in which the samples were collected was cleaned with dilute acid followed by distilled water, sterilized, narrow mouthed neutral glass stopper. Before sampling, the bottles were rinsed again three times with the water to be sampled. Water sample was transferred to $250 \mathrm{ml}$ plastic bottle which contained $1 \mathrm{ml}$ Alkaline Potassium Iodide solution for the analysis. Alkaline Potassium Iodide solution was used to protect water samples from any fungal and other pathogenic attack. After collection the bottles containing samples were sealed immediately to avoid exposure to air. The samples were taken from the mid-stream and few centimeters below the surface. To provide necessary information for each sample such as date of collection, location, time, etc. were recorded in the note book and each sample collected in a plastic bottle was labeled separately with a unique identification number. The water samples were carried out to the laboratory of Soil Science in Bangladesh Institute of Nuclear Agriculture (BINA) and concerned laboratory of JFCL. In these laboratories, the bottles were kept in a clean, cool and dry place for further analysis.

Sample analysis: The study was conducted through experimental method. The sample was analyzed through experiment with the independent variable which collected as sample from the study area of the
Jamuna River and Jamuna Fertilizer Company Limited. Temperature was measured by Celsius thermometer. Turbidity is measured by nephelometric turbidity meter with sample cell. The electrical conductivity (EC) of the samples was measured electrometrically by the EC meter, total dissolved solids (TDS) of the samples were determined electrometrically by the digital TDS meter. The hydrogen ion concentration $(\mathrm{pH})$ value of the water samples were determined electrometrically by $\mathrm{pH}$ meter. Dissolved oxygen (DO), Biological Oxygen Demand ( BOD), Ammonium and Nitrate were determined by following the APHA (1981).

\section{Results and Discussion}

The highest water temperature $37^{\circ} \mathrm{C}$ was found in effluent point and the lowest was $22^{\circ} \mathrm{C}$ in disposal point which is $200 \mathrm{~m}$ downstream of river water during the wet season. In wet season the level of temperature ranged from 29 to $37^{\circ} \mathrm{C}$ in station1 which was within the standard limit(table 1). In dry season the level of temperature varied from 29 to $36.2^{\circ} \mathrm{C}$ with the mean value of $31.69{ }^{\circ} \mathrm{C}$ and standard deviation 3.18 (Table 2). During the dry season in station -1 temperature was $29.5-40.2^{\circ} \mathrm{C}$ which is higher than wet season. The highest temperature $40.2^{\circ} \mathrm{C}$ was found in effluent point over the study period. Temperature of water samples was gradually decreasing from industrial effluent to river water.

The turbidity values were in the range of 27.5 to 134.66 NUT with the mean value of 63.20 NTU in the wet season (Table 1). In the dry season value of turbidity varied from 17.33 to 126.33 NTU with the mean value of 46.78 (Table 2). The highest turbidity value 214 NTU was found in effluent station and the lowest was $7.5 \mathrm{NTU}$ in water which is $200 \mathrm{~m}$ downstream of river water over the study period. Comparatively low water turbidity is found in dry season than those of the wet season. The high turbidity values obtained during the wet season can be attributed to high incidences of rainfall, which lead to increased erosion and surface runoff carrying a lot of suspended materials into the river. High turbidity values indicate the possible presence of micro-organisms, clays, silts and other suspended 
solids in water, which affect its aesthetic value by causing it to appear cloudy (Edokpayi, 2014).

Determination of physico-chemical properties of effluent and river water: Physico-chemical characteristics of the effluent discharged from the JFCL were determined by water sample analysis of the Jamuna River. The results of the different parameters are given below;

Table 1. Analysis of physico-chemical parameters of effluent and river water (wet season)

\begin{tabular}{|c|c|c|c|c|c|c|}
\hline Parameters & Station-1 & Station-2 & Station-3 & Station-4 & Mean \pm SD & $\begin{array}{c}\text { Standard } \\
\text { Value (DOE, } \\
\text { 2008) } \\
\end{array}$ \\
\hline $\begin{array}{c}\text { Temperature } \\
\left({ }^{\circ} \mathrm{C}\right)\end{array}$ & $\begin{array}{l}29-37 \\
(33.5)\end{array}$ & $\begin{array}{c}27-31 \\
(29)\end{array}$ & $\begin{array}{c}26-29.5 \\
(27.7)\end{array}$ & $\begin{array}{c}22-27 \\
(24.33)\end{array}$ & $63 \pm 3.79$ & $40-45$ \\
\hline $\begin{array}{l}\text { Turbidity } \\
\text { (NTU) }\end{array}$ & $\begin{array}{c}40-214 \\
(134.66)\end{array}$ & $\begin{array}{c}30-70 \\
(52)\end{array}$ & $\begin{array}{c}10-66 \\
(38.67)\end{array}$ & $\begin{array}{l}7.5-45 \\
(27.5)\end{array}$ & $63.20 \pm 48.67$ & - \\
\hline $\mathrm{pH}$ & $\begin{array}{c}8.9-9.7 \\
(9.3)\end{array}$ & $\begin{array}{l}7.5-8.6 \\
(8.05)\end{array}$ & $\begin{array}{c}7.2-8.2 \\
(7.76)\end{array}$ & $\begin{array}{c}7.1-7.5 \\
(7.3)\end{array}$ & $8.10 \pm 0.85$ & $6.0-9.0$ \\
\hline $\begin{array}{c}\mathrm{EC} \\
\left(\mu \mathrm{scm}^{-1}\right)\end{array}$ & $\begin{array}{c}1325-1755 \\
(1555.67)\end{array}$ & $\begin{array}{c}400-559 \\
(473)\end{array}$ & $\begin{array}{c}300-400 \\
(350)\end{array}$ & $\begin{array}{c}265-290 \\
(279)\end{array}$ & $664.41 \pm 599.54$ & 1200 \\
\hline $\begin{array}{l}\text { TDS } \\
(\mathrm{ppm})\end{array}$ & $\begin{array}{l}400-661 \\
(533.66)\end{array}$ & $\begin{array}{l}290-400 \\
(351.66)\end{array}$ & $\begin{array}{c}260-350 \\
(305)\end{array}$ & $\begin{array}{c}250-330 \\
(293)\end{array}$ & $370.91 \pm 111.38$ & 2100 \\
\hline $\begin{array}{c}\text { TSS } \\
(\mathrm{ppm})\end{array}$ & $\begin{array}{c}38-190 \\
(111)\end{array}$ & $\begin{array}{c}36-88 \\
(70.33)\end{array}$ & $\begin{array}{c}35.1-87.3 \\
(66.66)\end{array}$ & $\begin{array}{l}33.9-69 \\
(49.96)\end{array}$ & $74.49 \pm 25.90$ & 150 \\
\hline DO (ppm) & $\begin{array}{c}4.0-4.9 \\
(4.43)\end{array}$ & $\begin{array}{c}5.2-6.5 \\
(5.93)\end{array}$ & $\begin{array}{c}6.2-7.2 \\
(6.63)\end{array}$ & $\begin{array}{c}7.21-7.7 \\
(7.47)\end{array}$ & $6.11 \pm 1.28$ & $4.5-8.0$ \\
\hline $\begin{array}{l}\text { BOD } \\
(\mathrm{ppm})\end{array}$ & $\begin{array}{c}60-450 \\
(286.66)\end{array}$ & $\begin{array}{c}6.5-9.0 \\
(8.0)\end{array}$ & $\begin{array}{c}3.1-5.8 \\
(4.5)\end{array}$ & $\begin{array}{c}2.2-2.6 \\
(2.4)\end{array}$ & $75.39 \pm 140.86$ & 50 \\
\hline $\begin{array}{l}\text { Ammonium } \\
(\mathrm{ppm})\end{array}$ & $\begin{array}{l}620-905 \\
(741.66)\end{array}$ & $\begin{array}{l}150-304 \\
(234.66)\end{array}$ & $\begin{array}{l}110-130 \\
(119.66)\end{array}$ & $\begin{array}{c}70-110 \\
(91)\end{array}$ & $\begin{array}{l}296.74 \\
\pm 303.03\end{array}$ & 129 \\
\hline $\begin{array}{l}\text { Nitrite }\left(\mathrm{NO}_{2}\right) \\
(\mathrm{ppm})\end{array}$ & $\begin{array}{c}36-55.2 \\
(44.4)\end{array}$ & $\begin{array}{c}1.39-2.1 \\
(1.79)\end{array}$ & $\begin{array}{c}1.37-1.97 \\
(1.61)\end{array}$ & $\begin{array}{c}1.23-1.85 \\
(1.46)\end{array}$ & $12.31 \pm 21 . .38$ & - \\
\hline $\begin{array}{c}\text { Nitrate }\left(\mathrm{NO}_{3}\right) \\
(\mathrm{ppm})\end{array}$ & $\begin{array}{c}46.2-59.0 \\
(51.73)\end{array}$ & $\begin{array}{l}3.0-12 \\
(6.66)\end{array}$ & $\begin{array}{c}1.35-1.60 \\
(1.31)\end{array}$ & $\begin{array}{c}0.90-1.30 \\
(1.06)\end{array}$ & $15.19 \pm 24.49$ & 10 \\
\hline $\begin{array}{l}\text { Chloride } \\
\text { (ppm) }\end{array}$ & $\begin{array}{l}15-32.5 \\
(25.16)\end{array}$ & $\begin{array}{c}10-25 \\
(18)\end{array}$ & $\begin{array}{c}6.6-18.8 \\
(13.43)\end{array}$ & $\begin{array}{c}2.4-6.6 \\
(4.33)\end{array}$ & $15.23 \pm 8.72$ & 600 \\
\hline
\end{tabular}

Note: The mean values are in parenthesis

The TDS values in dry season of four sampling points recorded from 533.66 to 293.33 ppm with the mean value of $370.91 \mathrm{ppm}$ and standard deviation 111.38 (Table 1). The highest value of TDS was 661 ppm in the effluent station while the lowest value 250 ppm was found in disposal point was observed during wet season, which might be due to proper dilution of the effluents. TDS values were gradually decreasing from industrial effluent to river water.TDS values in dry season were ranged from 390-600 ppm with the mean of 480.0 in station-1.
The TDS values of four sampling points in dry were recorded from 281.83 to $480 \mathrm{ppm}$ with the mean value of $338.37 \mathrm{ppm}$ and standard deviation 94.70 (Table 2). The maximum TDS value 600 ppm was found in effluent station might be due to improper dilution of the discharged effluent in dry. The TDS values for both seasons are within the DOE (2008) tolerance limits. A maximum TDS value of $400 \mathrm{ppm}$ is permissible for diverse fish production (Chhatwal, 1998). So, we can also say that the river water at the $200 \mathrm{~m}$ downstream is suitable for fish production. 

Fatima et al. (2015), Progressive Agriculture 26 (2): 136-146

Table 2. Analysis of physico-chemical parameters of effluent and river water (dry season)

\begin{tabular}{|c|c|c|c|c|c|c|}
\hline Parameters & Station-1 & Station-2 & Station-3 & Station-4 & Mean \pm SD & $\begin{array}{c}\text { Standard } \\
\text { Value }\end{array}$ \\
\hline $\begin{array}{c}\text { Temperature } \\
\left({ }^{\circ} \mathrm{C}\right)\end{array}$ & $\begin{array}{c}29.4-40.2 \\
(36.2)\end{array}$ & $\begin{array}{c}28.1-35.6 \\
(31.56)\end{array}$ & $\begin{array}{c}28-32 \\
(30)\end{array}$ & $\begin{array}{c}27-31 \\
(29)\end{array}$ & $31.69 \pm 3.18$ & $40-45$ \\
\hline $\begin{array}{c}\text { Turbidity } \\
\text { (NTU) }\end{array}$ & $\begin{array}{c}30-189 \\
(126.33)\end{array}$ & $\begin{array}{c}10-35 \\
(23.16)\end{array}$ & $\begin{array}{l}9.0-29 \\
(20.33)\end{array}$ & $\begin{array}{c}7.5-25 \\
(17.33)\end{array}$ & $46.79 \pm 79$ & - \\
\hline $\mathrm{pH}$ & $\begin{array}{c}9.0-9.6 \\
(9.3)\end{array}$ & $\begin{array}{c}8.3-8.8 \\
(8.53)\end{array}$ & $\begin{array}{l}7.9-8.6 \\
(8.23)\end{array}$ & $\begin{array}{c}7.4-7.9 \\
(7.7)\end{array}$ & $8.44 \pm 0.66$ & $6.0-9.0$ \\
\hline $\begin{array}{c}\text { EC } \\
(\mu \mathrm{s} / \mathrm{cm})\end{array}$ & $\begin{array}{l}1300-1834 \\
(1594.66)\end{array}$ & $\begin{array}{c}500-755 \\
(635)\end{array}$ & $\begin{array}{l}450-657 \\
(555.33)\end{array}$ & $\begin{array}{c}300-400 \\
(360)\end{array}$ & $\begin{array}{c}786.25 \pm 551 \\
18\end{array}$ & 1200 \\
\hline $\begin{array}{l}\text { TDS } \\
(\mathrm{ppm})\end{array}$ & $\begin{array}{c}390-600 \\
(480)\end{array}$ & $\begin{array}{c}275-335 \\
(300)\end{array}$ & $\begin{array}{l}265-330 \\
(291.66)\end{array}$ & $\begin{array}{c}250.5-320 \\
(281.83)\end{array}$ & $\begin{array}{c}338.37 \pm 94.7 \\
0\end{array}$ & 2100 \\
\hline $\begin{array}{c}\text { TSS } \\
(\mathrm{ppm})\end{array}$ & $\begin{array}{c}40.9-290 \\
(160.3)\end{array}$ & $\begin{array}{c}28-56.4 \\
(44.8)\end{array}$ & $\begin{array}{l}26-54.3 \\
(42.76)\end{array}$ & $\begin{array}{l}25-51.4 \\
(40.46)\end{array}$ & $72.08 \pm 58.83$ & 150 \\
\hline $\begin{array}{c}\mathrm{DO} \\
(\mathrm{ppm})\end{array}$ & $\begin{array}{c}3.2-4.9 \\
(4.16)\end{array}$ & $\begin{array}{c}4.3-6.7 \\
(5.36)\end{array}$ & $\begin{array}{c}4.6-7.2 \\
(5.9)\end{array}$ & $\begin{array}{c}4.9-7.5 \\
(6.4)\end{array}$ & $5.45 \pm 0.95$ & $4.5-8.0$ \\
\hline $\begin{array}{l}\text { BOD } \\
(\mathrm{ppm})\end{array}$ & $\begin{array}{c}60-470 \\
(326.66)\end{array}$ & $\begin{array}{l}8.5-10 \\
(9.16)\end{array}$ & $\begin{array}{c}5.0-7.5 \\
(6.33)\end{array}$ & $\begin{array}{c}4.5 .-6.4 \\
(5.56)\end{array}$ & $\begin{array}{c}86.93 \pm 159.8 \\
2\end{array}$ & 50.0 \\
\hline $\begin{array}{l}\text { Ammonium } \\
\text { (ppm) }\end{array}$ & $\begin{array}{l}623-912 \\
(745.66)\end{array}$ & $\begin{array}{c}256-550 \\
(383)\end{array}$ & $\begin{array}{c}105-234 \\
(163)\end{array}$ & $\begin{array}{c}80-115 \\
(100)\end{array}$ & $\begin{array}{c}347.91 \pm 291 . \\
60\end{array}$ & 129 \\
\hline $\begin{array}{l}\text { Nitrite }\left(\mathrm{NO}_{2}\right) \\
(\mathrm{ppm})\end{array}$ & $\begin{array}{l}37.1-56 \\
(48.36)\end{array}$ & $\begin{array}{c}1.83-3.1 \\
(2.61)\end{array}$ & $\begin{array}{c}1.68-2.8 \\
(2.36)\end{array}$ & $\begin{array}{c}0.98-1.7 \\
(1.39)\end{array}$ & $13.68 \pm 23.12$ & - \\
\hline $\begin{array}{l}\text { Nitrate }\left(\mathrm{NO}_{3}\right) \\
(\mathrm{ppm})\end{array}$ & $\begin{array}{c}45-66 \\
(54.36)\end{array}$ & $\begin{array}{c}10.5-20.9 \\
(15.73)\end{array}$ & $\begin{array}{c}1.39-3.21 \\
(2.14)\end{array}$ & $\begin{array}{c}0.90-1.5 \\
(1.13)\end{array}$ & $18.34 \pm 24.92$ & 10 \\
\hline $\begin{array}{l}\text { Chloride } \\
\text { (ppm) }\end{array}$ & $\begin{array}{c}17-40 \\
(30.66)\end{array}$ & $\begin{array}{c}13-30 \\
(22.66 .)\end{array}$ & $\begin{array}{l}8.0-20 \\
(14.2)\end{array}$ & $\begin{array}{c}3.0-8.5 \\
(5.7)\end{array}$ & $18.3 \pm 9.32$ & 600 \\
\hline
\end{tabular}

Note: The mean values are in parenthesis

The highest value of TSS 290 ppm was recorded in the effluent in dry season might be due to low dilution of the discharged effluent. The lowest value of TSS $33.9 \mathrm{ppm}$ of the effluents was observed during wet season, which might be due to well dilution of the effluents. On the other hand, the lowest concentrations of TSS are found in the natural water of the river water due to the presence of greater dilution capacity. During wet season the highest load of TSS might be due to heavy rainfall and land-based run-off carrying a large volume of suspended silts and clays.

The highest $\mathrm{pH}$ value 9.7 was found in effluent points and the lowest was 7.1 (Fig. 1) in river water
(200 m downstream) during the study period. However, $\mathrm{pH}$ value of the effluents was always found higher than those of the effluent in discharged area and in the river water. It might be due to the presence of alkaline wastes in the industrial effluents. . Ahmed and Rahman (2000) reported that in most raw water sources $\mathrm{pH}$ lies in the range of 6.5-8.5. The $\mathrm{pH}$ value of the study area was slightly alkaline to strongly alkaline. The $\mathrm{pH}$ ranging from 6-9 is suitable for the existence of most biological life. An alkaline environment with a $\mathrm{pH}$ range 7.5-8.4 is good for the growth of algae and range 6.0-7.2 is optimum for fish eggs (EGIS II, 2002). 


\section{Effluents of fertilizer factory}
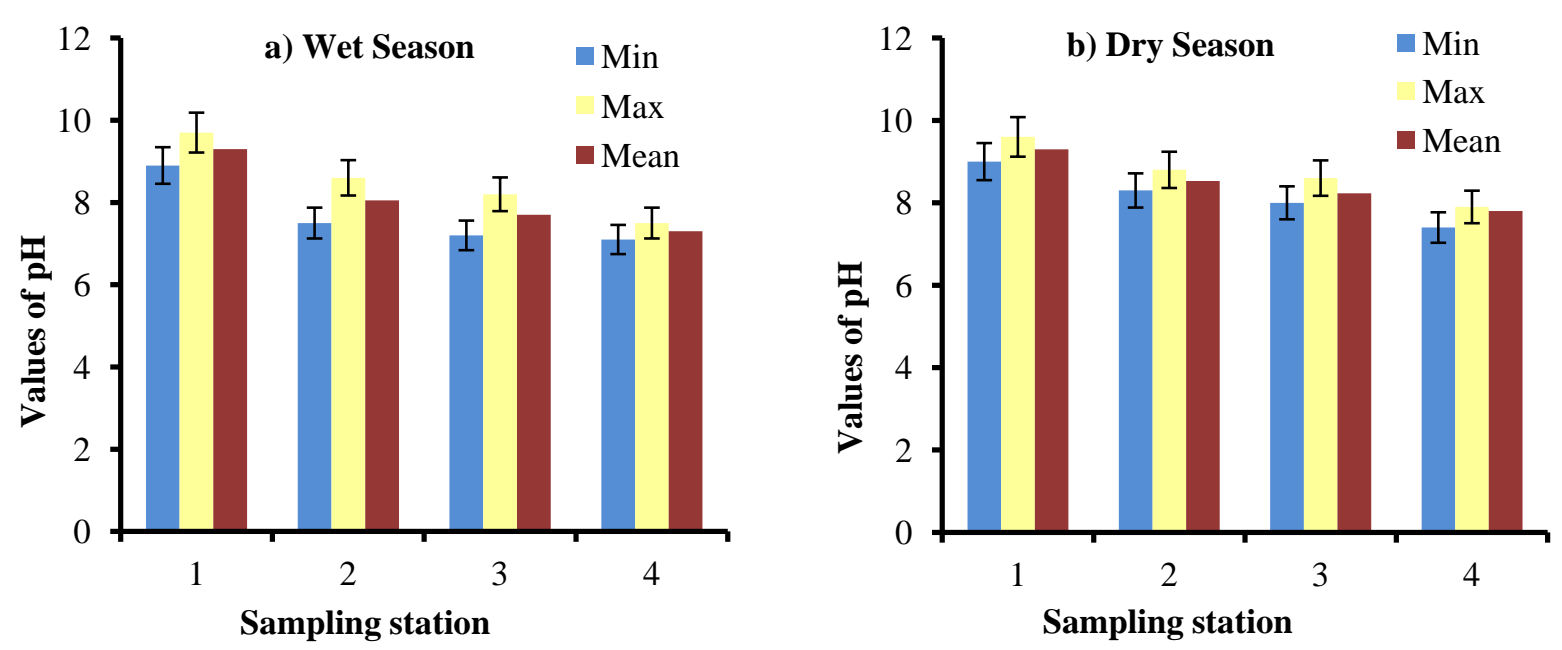

Figure1.Variation of $\mathrm{pH}$ of water samples in different stations in wet and dry season

The highest value of EC was $1834 \mu_{S_{c m}}^{-1}$ of the effluent in dry season (Fig. 2b) might be due to improper dilution of the discharged effluent. The EC values were relatively high in effluent point throughout the study period. The lowest value of EC $265 \mu \mathrm{Scm}^{-1}$ of the effluents and river water were observed during wet season(Fig. 2a) which might be due to proper dilution of the effluents. Electrical conductivity usually used for indicating the total concentration of ionized constituents of water (Huq

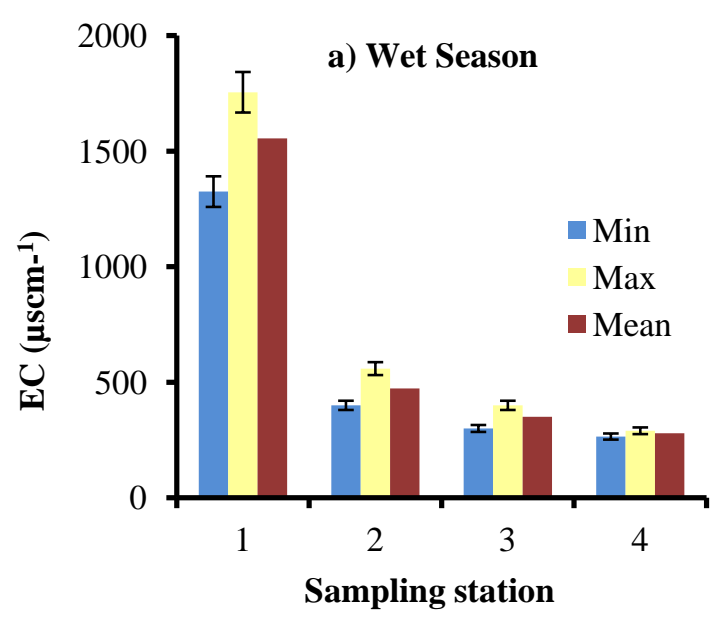

and Alam, 2005). The highest value of EC 1834 $\mu \mathrm{Scm}^{-1}$ in effluent point was higher than the standard values (ECR, 1997). Studies of inland fresh waters indicate that streams supporting good mixed fisheries have a range between 150 and $500 \mu \mathrm{Scm}^{-1}$. EC outside this range could indicate that the water is not suitable for certain species of fish or microinvertebrates.

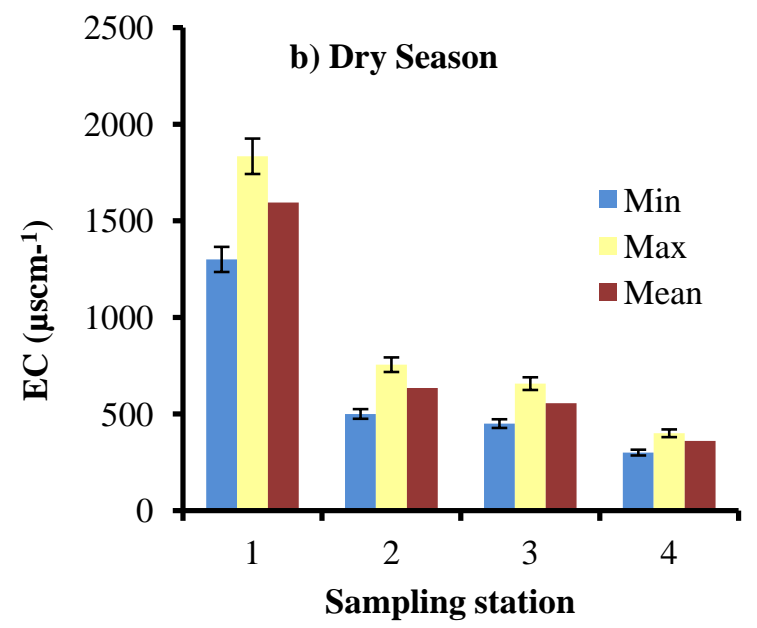

Figure 2. Variation of EC of water samples in different stations in wet and dry season

From the investigation, the mean values of DO at different sampling points in wet season ranged from 4.43 to $7.7 \mathrm{ppm}$. The mean value of them was 6.11 ppm and standard deviation 1.28 (Table 1). ). It was observed that in wet season the dissolved oxygen contents was found in effluent station ranged from 4.0-4.9 ppm with the mean \pm SD $4.43 \pm 0.45$. The average DO contents in wet season were $5.93 \pm 0.66$ ppm, $6.63 \pm 0.51 \mathrm{ppm}$ and $7.47 \pm 0.24 \mathrm{ppm}$ in station2, 3 and 4, respectively(Fig. 3 a).The DO level in other station-2, 3 and 4 were found to ranges from 4.3-6.70 ppm, 4.6-7.2 and 4.9-7.5 ppm, respectively (Fig. $3 \mathrm{~b}$ ). The DO of the effluents $3.2 \mathrm{ppm}$ was found lower than those of the effluent discharged 
area DO was $4.9 \mathrm{ppm}$ and in the river water. The lower DO content of the effluents might be due to the high content of the suspended and dissolved solids utilizing significant amount of dissolved oxygen for biochemical degradation. The investigation showed
DO contents of industrial effluent were lower than standard value (Ahmed and Rahman, 2000) in both seasons. The value of DO observed higher in wet season might be due to the lowest water temperature as well as well aeration of the effluents
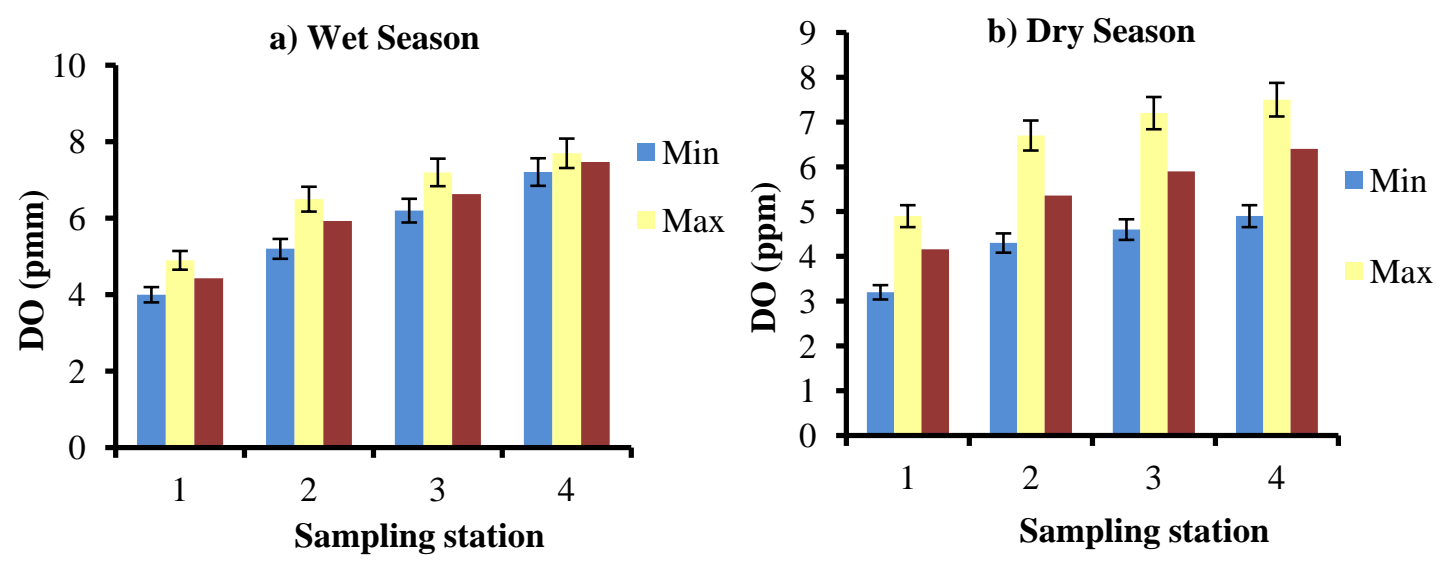

Figure 3.DO contents of water samples at different stations in wet and dry season

The effluents of the JFCL always showed a higher value of BOD while BOD level of the effluent discharged area and in the river throughout the period of investigation. It might be due to the presence of large quantities of organic matters i.e., dissolved and suspended solids in the effluents and effluent discharged area, decomposition of which utilized significant amount of DO from the respective water bodies. In dry season the level of biological oxygen demand was found in station-1was 60-470 ppm with mean value of $326.66 \mathrm{ppm}$ and standard deviation 231.15. The investigation showed that the mean values of BOD in station-2, 3 and 4 were found $9.16 \mathrm{ppm}, 6.33 \mathrm{ppm}$ and $5.56 \mathrm{ppm}$, respectively (Fig. 12 b). BOD value 470 ppm was found higher in dry season and the BOD value was negatively correlated with the DO value.

Sabbir et al. (2010) reported that water quality parameter on Mouri river where found the value of BOD did not maintain any relation with the change of the seasons or any other natural factors. The biodegradation of organic materials exerts oxygen tension in the water and increases the biological oxygen demand (Abida and Harikrishna, 2008). The
BOD value in station-2 exceeds standard value of surface inland water. Unpolluted waters typically have BOD values of 2 ppm or less (Chapman, 1996). The highest concentration of ammonium 905 ppm was found at the effluent point (station-1)and the lowest concentration 70 ppm was observed at station -4 which was $200 \mathrm{~m}$ downstream of river water during wet (Fig. 4a). The presence of $\mathrm{NH}^{4+}$ in the effluents was much higher throughout the period of investigation. Among the elements discharged from the JFCL, $\mathrm{NH}_{3}$ was the most poisonous and objectionable gas, which come out in higher concentration. The ammonium ion concentration was found higher in effluent water than those of river water and its concentration gradually decreases from Station-1 to station-4 because river water has greater dilution capacity. The highest concentration of ammonium 912 ppm was found at the effluent point (station-1) and the lowest concentration 80 ppm was observed at station- 4 in dry (Fig.4b). The value of ammonium ion concentration was found slightly higher in dry season than those of wet season because in dry season less quantity of water remains in the river and in wet season has great dilution capacity. 

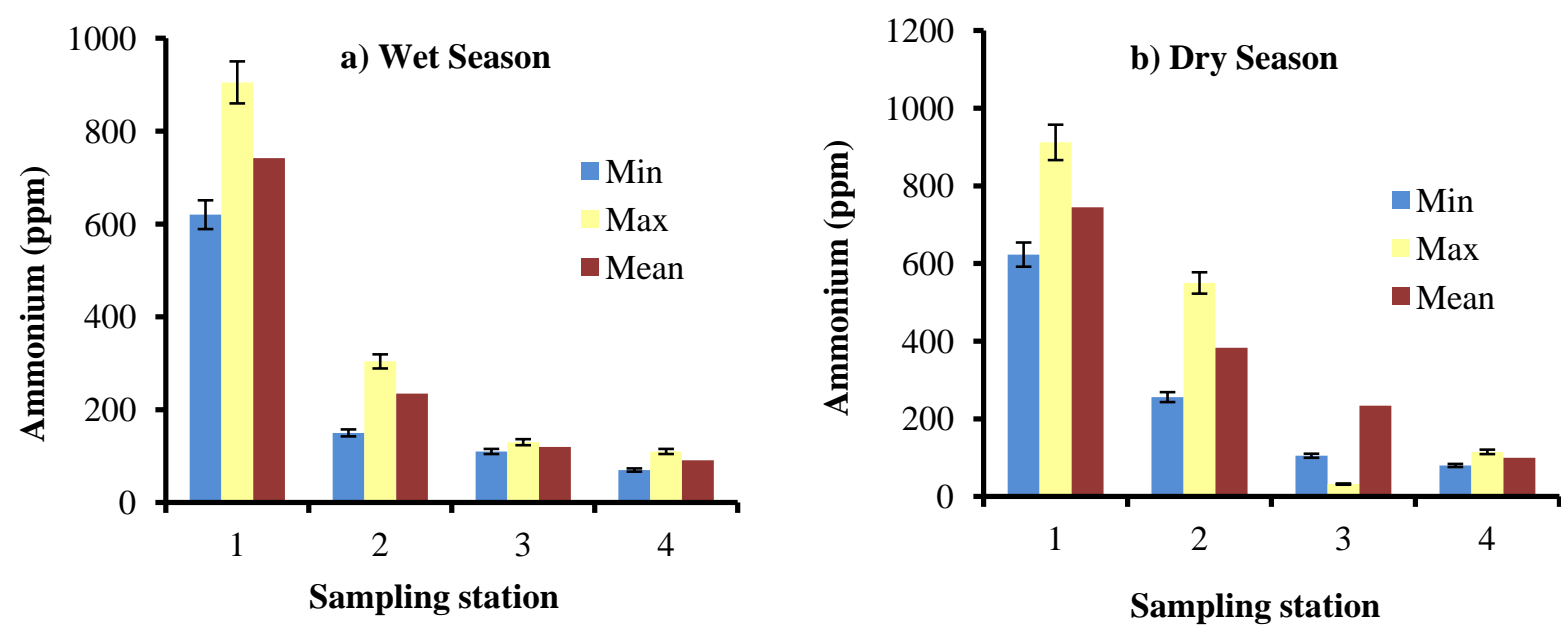

Figure 4. Ammonium $\left(\mathrm{NH}_{4}{ }^{+}\right)$concentration of samples at different stations in wet and dry season

The average nitrate concentration in wet season varied between $51.73 \pm 6.57 \mathrm{ppm}, 6.66 \pm 4.72 \mathrm{ppm}$, $1.31 \pm 0.30 \mathrm{ppm}$, and $1.06 \pm 0.20 \mathrm{ppm}$ in station- 1 , station-2, station-3 and station-4, respectively (Fig.5 a) while in dry season $54.36 \pm 10.68 \mathrm{ppm}, 15.73 \pm$ $5.20 \mathrm{ppm}, 2.14 \pm 0.95 \mathrm{ppm}$ and $1.13 \pm 0.32 \mathrm{ppm}$ values were recorded for station- 1 , station-2, station3 and station-4, respectively (Fig. 5 b). The nitrate ion concentration of the effluent discharge area was foun dfluctuating regularly with the fluctuation of nitrate in the effluent water. The lowest nitrate concentration was recorded $0.90 \mathrm{ppm}$ at the staion-4 in both seasons. The effluents showed the highest value of nitrate while the effluent discharged area

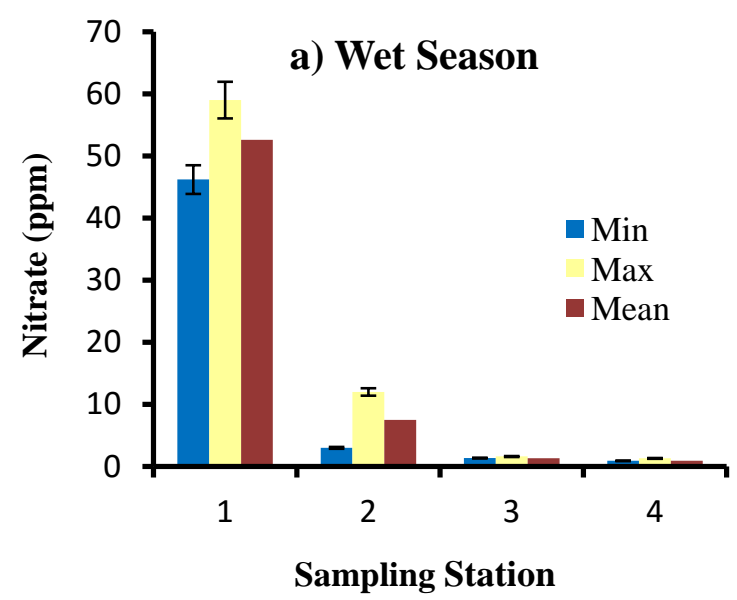

showed remarkable higher value than that of the river water during the period of investigation. The average nitrate $\left(\mathrm{NO}_{3}\right)$ concentration was higher in the dry season than in the wet season. A similar observation was reported by Anhwange et al. (2012), Adeyemo et al. (2008) and Shrestha and Kazama (2007). The concentrations of $\mathrm{NO}_{3}$ are usually built up during the dry season while in the wet season there is high dilution due to high rainfall events. These are the possible reasons for the slightly higher concentration of nitrate observed in the dry season (Adeyemo, 2008). The concentrations of $\mathrm{NO}_{3}$ in effluent point exceeded the DOE (2008) threshold limits for domestic water use and the concentration determined can induce eutrouphication.

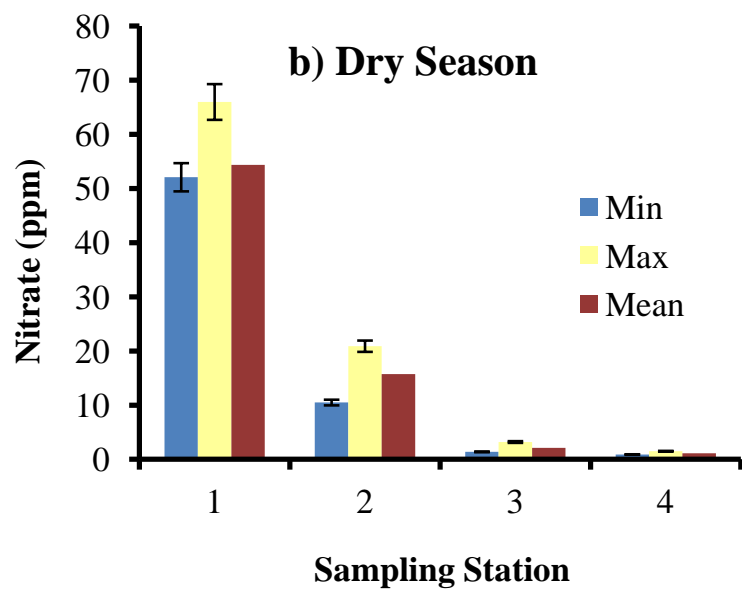

Figure 5. Nitrate $\left(\mathrm{NO}_{3}\right)$ concentration of samples at different stations in wet and dry season 
Fatima et al. (2015), Progressive Agriculture 26 (2): 136-146

Correlation coefficient matrix for effluent and river water quality parameters in wet and dry season: Correlation matrix for analyzed parameters of effluent and river water were calculated to find out interrelationship with each other. The correlation matrixes have been presented in Table 3 and 4.

Table 3. Pearson correlation matrix of physico-chemical parameters of effluent and river water during wet season

\begin{tabular}{|c|c|c|c|c|c|c|c|c|c|c|c|}
\hline & Temp & Turbidity & $\mathrm{pH}$ & EC & TDS & TSS & DO & BOD & Ammonium & Nitirte & Nitrate \\
\hline Temp & 1 & & & & & & & & & & \\
\hline Turbidity & $0.826^{\text {*t }}$ & 1 & & & & & & & & & \\
\hline $\mathrm{pH}$ & $0.849^{* *}$ & $0.773^{\star *}$ & 1 & & & & & & & & \\
\hline EC & $0.676^{*}$ & $0.752^{* *}$ & $0.864^{* *}$ & 1 & & & & & & & \\
\hline TDS & $0.868^{* *}$ & $0.864^{* *}$ & $0.914^{* *}$ & $0.789^{* *}$ & 1 & & & & & & \\
\hline TSS & $0.754^{\star *}$ & $0.926^{* *}$ & $0.641^{*}$ & $0.584^{\star}$ & $0.693^{\star}$ & 1 & & & & & \\
\hline DO & $-0.619^{\star}$ & $-0.506^{\mathrm{N} / \mathrm{S}}$ & $-0.750^{* *}$ & $-0.831^{\text {*k }}$ & $-0.674^{\star}$ & $-0.261^{N / S}$ & 1 & * & & & \\
\hline BOD & $0.789^{\text {*k }}$ & $0.878^{\star *}$ & $0.788^{* *}$ & $0.774^{\star *}$ & $0.929^{\text {*t }}$ & $0.688^{*}$ & $-0.628^{\star}$ & 1 & & & \\
\hline Ammonium & $0.805^{\text {tk }}$ & $0.787^{\star \star}$ & $0.922^{\text {** }}$ & $0.924^{\star *}$ & $0.936^{\text {t* }}$ & $0.570^{*}$ & $-0.830^{* *}$ & $0.894^{* *}$ & 1 & & \\
\hline Nitirte & $0.735^{\star \star}$ & $0.761^{\star *}$ & $0.864^{\star *}$ & $0.927^{\star *}$ & $0.894^{\star x}$ & $0.529 \mathrm{~N} / \mathrm{S}$ & $-0.795^{\star \star}$ & $0.914^{* *}$ & $0.974^{\star *}$ & 1 & \\
\hline Nitrate & $0.706^{\star}$ & $0.794^{\star *}$ & $0.879^{* *}$ & $0.988^{* *}$ & $0.848^{* k}$ & $0.608^{\star}$ & $-0.811^{\star *}$ & $0.852^{* *}$ & $0.956^{* *}$ & $0.963^{* *}$ & 1 \\
\hline Chloride & $0.905^{\star \star}$ & $0.807^{\star \star}$ & $0.885^{\star *}$ & $0.658^{\star}$ & $0.879^{* k}$ & $0.735^{\star \star}$ & $-0.624^{\star}$ & $0.736^{* *}$ & $0.789^{* *}$ & $0.679^{*}$ & $0.682^{\star}$ \\
\hline
\end{tabular}

Legend: $* *=$ Correlation is significant at the $1 \%$ level, $*=$ Correlation is significant at the $5 \%$ level, N/S = Not Significant

Table 4. Pearson correlation matrix of physic-chemical parameters of effluent and river water during dry season

\begin{tabular}{|c|c|c|c|c|c|c|c|c|c|c|c|}
\hline & Temp & Turbidity & $\mathrm{pH}$ & EC & TDS & TSS & DO & BOD & Ammonium & Nitirte & Nitrate \\
\hline Temp & 1 & & & & & & & & & & \\
\hline Turbidity & $0.860^{* *}$ & 1 & & & & & & & & & \\
\hline $\mathrm{pH}$ & $0.730^{\text {** }}$ & $0.785^{\star k}$ & 1 & & & & & & & & \\
\hline EC & $0.674^{*}$ & $0.767^{\star *}$ & $0.878^{* *}$ & 1 & & & & & & & \\
\hline TDS & $0.786^{* *}$ & $0.917^{\text {* }}$ & $0.805^{* *}$ & $0.871^{* *}$ & 1 & & & & & & \\
\hline TSS & $0.716^{* *}$ & $0.872^{* *}$ & $0.654^{*}$ & $0.570^{\star}$ & $0.689^{\star}$ & 1 & & & & & \\
\hline DO & $-0.055^{\mathrm{N} / \mathrm{S}}$ & $-0.286^{\mathrm{N} / \mathrm{S}}$ & $-0.507^{N / S}$ & $-0.539^{N / S}$ & $-0.398^{\mathrm{N} / \mathrm{S}}$ & $-0.182^{N / S}$ & 1 & & & & \\
\hline BOD & $0.814^{\text {t* }}$ & $0.987^{* k}$ & $0.755^{\star \star}$ & $0.767^{\text {*k }}$ & $0.898^{* *}$ & $0.895^{* *}$ & $-0.333^{N / S}$ & 1 & & & \\
\hline Ammonium & $0.670^{*}$ & $0.800^{* *}$ & $0.871^{\text {** }}$ & $0.867^{\star \star}$ & $0.878^{* \star}$ & $0.639^{*}$ & $-0.633^{*}$ & $0.804^{* *}$ & 1 & & \\
\hline Nitirte & $0.710^{\text {** }}$ & $0.896^{* *}$ & $0.826^{\text {** }}$ & $0.934^{* *}$ & $0.915^{\star \star}$ & $0.786^{* *}$ & $-0.52^{\mathrm{N} / \mathrm{S}}$ & $0.920^{* *}$ & $0.885^{* *}$ & 1 & \\
\hline Nitrate & $0.543^{\mathrm{N} / \mathrm{S}}$ & $0.643^{*}$ & $0.815^{* \star}$ & $0.919^{\text {*k }}$ & $0.738^{* *}$ & $0.589^{*}$ & $-0.617^{\star}$ & $0.672^{*}$ & $0.857^{* *}$ & $0.887^{* *}$ & 1 \\
\hline Chloride & $0.626^{*}$ & $0.763^{* *}$ & $0.841^{* \star}$ & $0.649^{*}$ & $0.745^{\star \star}$ & $0.653^{*}$ & $-0.515^{\mathrm{N} / \mathrm{S}}$ & $0.759^{* *}$ & $0.861^{* *}$ & $0.707^{\star}$ & $0.594^{*}$ \\
\hline
\end{tabular}

Legend: $* *=$ Correlation is significant at the $1 \%$ level, $*=$ Correlation is significant at the $5 \%$ level, N/S = Not Significan 


\section{Conclusion}

The effluent and water at the dumping sites from the JFCL emits noxious smell (ammoniacal odor) that are dangerous for aquatic ecosystem and human health which violates the standard values. DO exhibited significant negative correlation with $\mathrm{pH}$, EC, BOD, TDS, TSS, ammonium, nitrite and chloride respectively. It was noted that the concentration of most of the water quality parameters is higher in dry season than those of the wet season. The value of most of the physico-chemical parameters in effluent station and disposal station (both wet and dry seasons) is greater than the standard level. So it can be concluded that there was insignificant impact of various parameters discharged from fertilizer factories. The result suggested that water in the river was polluted and not good for human consumption.

\section{References}

Abida B and Harikrishna(2008). Study on the Quality of Water in Some Streams of Cauvery River. E-Journal of Chemistry, 5(2): 377-384.

Adeyemo OK, AdedokunOA,Yusuf RK, and Adeleye EA(2008). Seasonal changes in physico-chemical parameter and nutrient load of river sediments in Ibadan city Nigeria.Glob. NEST J., 10: 326-336.

Ahmad T (2012). Study on influence of effluent discharged from Ashuganj Fertilizer Industry on water quality of adjacent Meghnariver. M.Sc. Thesis: Dept. of Environmental Science and Resources Management, MawlanaBhashani Science and Technology University, pp. 15-55.

Ahmed MF and Rahman MM (2000). Water supply and sanitation, ITN Bangladesh, center for water supply and waste management, BUET, Dhaka, Bangladesh.

Alam MK (1997). Pollution Effects of Zia Fertilizer Factory on the River water of the Meghna. Bangladesh Journal of Water Resource Research.BUET,Dhaka, pp.14-18.

Anhwange BA, Agbaji EB andGimba EC (2012). Impact assessment of human activities and seasonal variation on River Benue, within
MakurdiMetropolis.Int. J. Sci. Techno, 2: 248259.

APHA (American Public Health Association) (1981). Standard methods for the examination of water and waste water, $15^{\text {th }}$ edition, Public Health Association, American Water Works association and Water Pollution Control Federation, Washington DC, pp. 1134.

Buchholz RA (1998). Principles of environmental management. The Greening of Business, 2nd.Prentice-Hall, London, UK.

Chapman D (1996). Water Quality Assessment: A Guide to the Use of Biota, Sediments and Water in Environmental Monitoring. $2^{\text {nd }}$ Edition, UNESCO/ WHO/ UNEP.

Chhatwal GR (1998). Encyclopedia of Environmental Biology.Anmol Publication Private Ltd., New Delhi, India, 2: 287-301.

DOE (Department of Environment) (2008). Guide for Assessment of Effluent Treatment Plants. Ministry of Environment and Forest Bangladesh, pp. 3-9.

ECR (Environmental Conservation Rules) (1997). The Environmental Conservation Rules. Government of the People's Republic of Bangladesh. Ministry of Environment and Forest, pp. 205-207.

Edokpayi JN, Odiyo JO and Olasoji SO (2014). Assessment of heavy metal contamination of Dzindi River, in Limpopo Province, South Africa.Int. J. Nat. Sci. Res.,2: 185-194.

EGIS II (Environmental and Geographic information Services) (2002). Water Quality Approach: Draft Final Report. Ministry of Empowering Communities in Wetland Fisheries Management.

Fakayode SO (2005). Impact of industrial effluents on water quality of the receiving Alaro River in Ibadan.Nigeria, Ajeam-Ragee., 10: 1-13.

HuqSMI and AlamMD (2005). A Handbook on Analysis of Soil plant and Water. BACER-DU, University of Dhaka, Bangladesh, pp. 246.

Klein L (1962). River Pollution: Causes and Effects. Butter Worths and Co. Ltd., London. 2:456.

Rahman ML (2000). Polltion effects of the Jamuna fertilizer company limited on the river water of 
Jamuna. Tech. J. River Research Institute, pp.56-63.

Sabbir W, Masud MAA, Islam SS, Rahman MA, Islam MR and RahiML (2010). Some aspects of water quality parameters of the Mouririver, Khulna: an attempt to estimate pollution status. J.Bangladesh Resources Publication, 4(1): 95-102.
Shrestha S and KazamaF (2007). Assessment of surface water quality using multivariate statistical techniques: A case study of the Fuji river basin, Japan. Environ. Model. Softw, 22: 464-475.

WARPO (Water Resource Planning Organization) (2000).Annex G: Environment, National Water Management Plan Project, Ministry of Water Resource, Government of Bangladesh. 